\title{
Domestic Accident
}

National Cancer Institute

\section{Source}

National Cancer Institute. Domestic Accident. NCI Thesaurus. Code C34342.

An accident taking place within a home. 